\title{
Effect of 3-D Modeling on Design of Pre-Engineered Steel Buildings
}

\author{
Ramesh Vasudeo Meghrajani ${ }^{1}$, Dr. R. K. Ingle ${ }^{2}$ \\ ${ }^{I}$ Research Scholar, Dept. of Applied Mechanics, Visvesvaraya National Institute of Technology, Nagpur, India. \\ ${ }^{2}$ Professor, Dept. of Applied Mechanics, Visvesvaraya National Institute of Technology, Nagpur, India.
}

\begin{abstract}
Professional engineers in Pre-engineered buildings (PEB) generally adopt two dimensional (2-D) modeling of frame i.e. plane frame modeling in transverse direction and profess for optimal design using elastic method. In practice, 2-D modeling of main frame is done for transverse frame while in longitudinal direction truss analogy is adopted mainly for analysis of bracing. In 2-D analysis majority of cases only major axis moment is considered and the minor axis moment (having sometimes significant effect on design) is generally ignored. This minor axis moment can be of less magnitude if the bracings are of $X$ type designed as compression as well as tensile members. However in practice these bracings are designed as tension only members, leading to significant effect of minor axis moments. It is also reported that if the ratio of deflections at knee joint in direction of ridge from second order analysis $\left(\Delta_{2}\right)$ versus first order $\left(\Delta_{1}\right)$, is 1.5 or more, second order analysis is must, however most of the cases in practice this factor is ignored.

This study is aimed to check and quantify the effect due to minor axis moment, i.e. $M_{y}$, in braced frames at knee joint. In absence of second order analysis, as mandated by codes, an approximate practical approach is presented for assessment of the minor axis moment, $M_{y}$, in terms of major axis frame moment, $M_{z}$. It is observed that the ratio of building height to width is significant in determining ratio $M_{y} / M_{z}$.
\end{abstract}

Keywords: 2-D analysis, 3-D analysis, Cross bracing, Minor axis Moments,, Pre-engineered buildings, PEB,.

\section{Introduction}

Pre-engineered steel buildings are modeled as series of plane frames with longitudinal stability provided by cross bracing and diaphragm action provided by sheeting. Frames are designed for forces obtained by 2-D frame analysis in transverse direction and truss action is adopted for evaluation of longitudinal forces in braces. Though various codes are now advocating limit state method and second order analysis, practicing engineers have been reluctant to adopt the detailed analysis including second order effects. Especially for the case where deflection ratio of second order to first order analysis, $\Delta_{2} / \Delta_{1}$, is more than 1.50 , second order analysis is recommended by Steel Construction Manual $\left(14^{\mathrm{TH}} \text { edition, 2011) }\right)^{[1]}$ and AISC Steel Design Series $25 .^{[2]}$

This study reviews current practice of analysis using 2-D model for design and compares the design aspect with 3-D analysis considering bracing designed as tension only member, in terms of major and minor axes moments and deflections at knee. Study is extended to review the relation between building height to width ratio, $\mathrm{h} / \mathrm{w}$, and minor axis moments at knee. In absence of 3-D analysis, an approximate method is proposed for assessment of minor axis moments.

\section{Current Methodology}

Newman ${ }^{[3]}$ describes current methodology for design of PEB buildings which is based on 2-D analysis with following assumptions.

(i) Frame remains in perfect vertical position.

(ii) Diaphragm action by roof and wall framing structure with sheeting provide stability in longitudinal direction and differential deflections are negligible.

(iii) Longitudinal wind forces are applied on endwall columns and are transferred to column bases by truss action.

(iv) All the cross bracing rods or relative bracing are defined as tension only members. ${ }^{[8]}$

(v) Frame components are not subjected to minor axis moments and relied on 2-D analysis.

Author has recommended alternate bays to be braced. 


\section{Three Dimensional Modeling of Pre-Engineered Steel Building}

Details of sections are given in Fig. 1 with wireframe and extruded models.

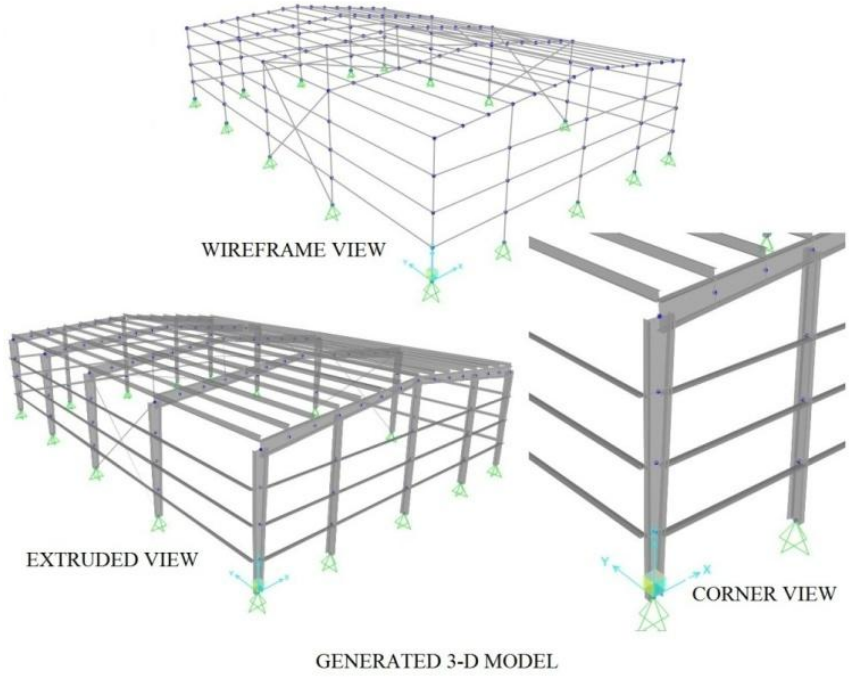

Fig.1 Three Dimensional Model Generated - Wireframe and Extruded models

The frame is loaded with dead load (DL) of $0.10 \mathrm{kN} / \mathrm{m}^{2}$ and live load (LL) ${ }^{[6]}$ as $0.75 \mathrm{kN} / \mathrm{m}^{2}$. Wind loads are considered along frame (WL-T) and along ridge (WL-L) directions for closed building with internal wind pressure (WI) coefficient 0.20 . Roof slope is considered to $1: 10$ i.e. $5.71^{\circ}$. Fig 2 shows primary loads on the frame.

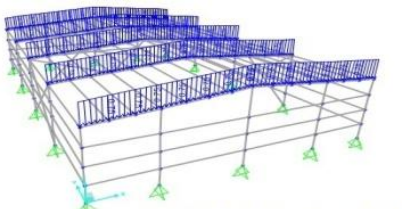

DEAD LOAD $=0.75 \mathrm{kN} / \mathrm{M}$
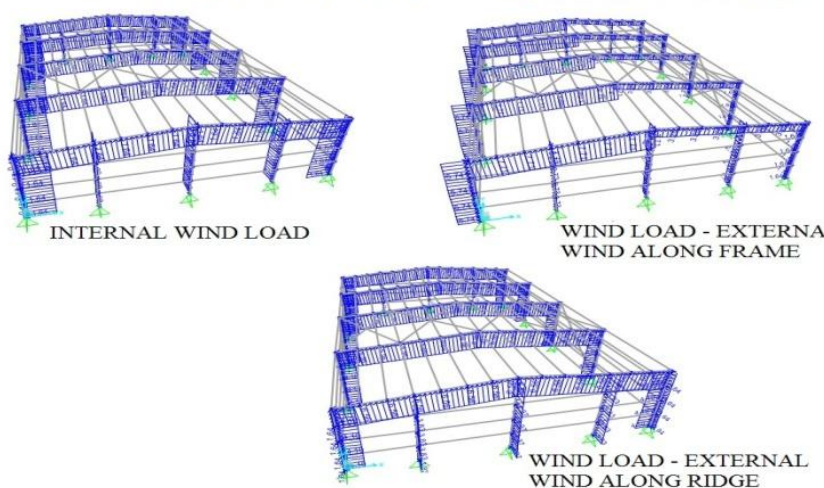

Fig. 2 Primary Loads - Dead, Live and Wind - Internal, Along Frame and Ridge

In this study buildings are considered with span varying from $12 \mathrm{~m}$ to $24 \mathrm{~m}$ (in increment of $2 \mathrm{~m}$ ), height of $6-9 \mathrm{~m}$ (in increment of $1 \mathrm{~m}$ ), length of building of $30.0 \mathrm{~m}$ and $45.0 \mathrm{~m}$, with bay spacing of $7.50 \mathrm{~m}$. In this $30 \mathrm{~m}$ building is considered with single braced bay while $45.0 \mathrm{~m}$ length building is with two braced bays. Single endwall column for building with upto $15 \mathrm{~m}$ and three columns above $15 \mathrm{~m}$ width are considered.

Load combinations considered are as follows:

a. Dead Load (DL) + Live Load (LL).

b. Dead Load (DL) + Wind Left along Frame(WL-T) + Wind Internal(WI)

c. Dead Load (DL) + Wind Left along Frame(WL-T) - Wind Internal(WI).

d. Dead Load(DL) + Wind along Ridge(WL-R) + Wind Internal (WI).

e. Dead Load(DL) + Wind along Ridge(WL-R) - Wind Internal (WI).

The following procedure is adopted for study and results are presented for $20 \mathrm{~m}$ wide building and $6 \mathrm{~m}$ height. 


\section{2-D Analysis}

With the data described above, 2-D analysis is performed. Working stress design method ${ }^{[4,5]}$ is used to calculate interaction factor (actual stress / allowable stress <1) due to major axis moment at knee governing load combination for fully braced combination. The procedure is adopted for all the frames and results of moments, section sizes, interaction factor etc. are presented in Table 1. This method is generally adopted in design offices.

Table 1 Major Axis Moments by 2-D Analysis and Full Braced Design at Knee

\begin{tabular}{|c|c|c|c|c|c|c|c|c|c|}
\hline $\begin{array}{l}\text { Heig } \\
\text { ht }\end{array}$ & $\begin{array}{l}\text { MAIC } \\
\text { LOAI } \\
\text { (a) }\end{array}$ & \multicolumn{3}{|c|}{ MAIOR AXIS MOMENTS (kN-M) } & & $\begin{array}{l}\text { Design Moment } \\
\text { M }_{n d}\end{array}$ & \multirow[t]{2}{*}{$\begin{array}{l}\text { SECTION SIZES } \\
\text { Web and Flanges }\end{array}$} & \multirow{2}{*}{$\begin{array}{l}\text { Actual Stress, } \\
\mathrm{F}_{\text {sesul }}=\mathrm{M}_{\mathrm{s}} \mathrm{S}_{\mathrm{z}} \\
\mathrm{Mpa}\end{array}$} & \multirow{2}{*}{$\begin{array}{l}\text { UNITY } \\
\text { CHECK = } \\
\mathrm{F}_{\text {antal }} / \mathrm{F}_{\text {allaw }} \\
\mathrm{Uc}_{\mathrm{c}}\end{array}$} \\
\hline $\mathrm{m}$ & \multirow{2}{*}{\multicolumn{5}{|c|}{$\begin{array}{l}\mathrm{kN}-\mathrm{m} \\
\text { Frame Span } 12 \mathrm{~m}\end{array}$}} & $\mathrm{kN}-\mathrm{m}$ & & & \\
\hline & & & & & & & & & \\
\hline 6 & 76 & 123 & 88 & 78 & 41 & 123 & $350 x 6+180 x 8$ & 198.5 & 0.96 \\
\hline 7 & 75 & 144 & 108 & 78 & 42 & 144 & $400 x 6+180 x 8$ & 196.8 & 0.95 \\
\hline 8 & 73 & 167 & 131 & 80 & 42 & 167 & $450 \times 6+180 \times 8$ & 198.2 & 0.96 \\
\hline \multirow[t]{2}{*}{9} & 71 & 194 & 158 & 82 & 43 & 194 & $500 x 6+180 x 8$ & 201.6 & 0.97 \\
\hline & \multicolumn{9}{|c|}{ Frame Span $14 \mathrm{~m}$} \\
\hline 6 & 106 & 147 & 99 & 106 & 57 & 147 & $400 x 6+180 x 8$ & 201.7 & 0.97 \\
\hline 7 & 104 & 167 & 119 & 106 & 57 & 167 & $450 \times 6+180 x 8$ & 198.1 & 0.96 \\
\hline 8 & 102 & 190 & 142 & 106 & 57 & 190 & $500 x 6+180 x 8$ & 197.5 & 0.95 \\
\hline \multirow[t]{2}{*}{9} & 100 & 217 & 169 & 108 & 57 & 217 & $550 x 6+180 x 8$ & 199.7 & 0.96 \\
\hline & \multicolumn{9}{|c|}{ Frame Span $16 \mathrm{~m}$} \\
\hline 6 & 140 & 175 & 117 & 139 & 75 & 175 & $475 \times 6+180 \times 8$ & 193.9 & 0.94 \\
\hline 7 & 138 & 195 & 132 & 139 & 74 & 195 & $500 x 6+180 x 8$ & 202.1 & 0.98 \\
\hline 8 & 136 & 217 & 155 & 139 & 74 & 217 & $550 x 6+180 x 8$ & 199.7 & 0.96 \\
\hline \multirow[t]{2}{*}{9} & 134 & 242 & 181 & 139 & 74 & 242 & $600 x 6+180 x 8$ & 199.4 & 0.96 \\
\hline & \multicolumn{9}{|c|}{ Frame Span $18 \mathrm{~m}$} \\
\hline 6 & 179 & 206 & 126 & 177 & 95 & 206 & $525 \times 6+180 \times 8$ & 201.6 & 0.97 \\
\hline 7 & 177 & 226 & 146 & 176 & 94 & 226 & $575 \times 6+180 \times 8$ & 196.3 & 0.95 \\
\hline 8 & 175 & 248 & 169 & 176 & 94 & 248 & $600 x 6+180 x 8$ & 203.9 & 0.98 \\
\hline \multirow[t]{2}{*}{9} & 172 & 272 & 195 & 175 & 94 & 272 & $650 \times 6+180 \times 8$ & 202.0 & 0.98 \\
\hline & \multicolumn{9}{|c|}{ Frame Span $20 \mathrm{~m}$} \\
\hline 6 & 223 & 241 & 142 & 219 & 118 & 241 & $600 x 6+180 x 8$ & 198.6 & 0.96 \\
\hline 7 & 221 & 260 & 162 & 218 & 117 & 260 & $625 \times 6+180 \times 8$ & 203.3 & 0.98 \\
\hline 8 & 219 & 282 & 186 & 217 & 116 & 282 & $675 \times 6+180 \times 8$ & 199.1 & 0.96 \\
\hline \multirow[t]{2}{*}{9} & 216 & 306 & 211 & 217 & 116 & 306 & $700 \times 6+180 \times 8$ & 205.9 & 0.99 \\
\hline & \multicolumn{9}{|c|}{ Frame Span $22 \mathrm{~m}$} \\
\hline 6 & 271 & 279 & 159 & 266 & 143 & 279 & $675 \times 6+180 \times 8$ & 197.2 & 0.95 \\
\hline 7 & 270 & 299 & 180 & 265 & 142 & 299 & $700 x 6+180 x 8$ & 200.9 & 0.97 \\
\hline 8 & 268 & 320 & 203 & 264 & 141 & 320 & $725 \times 6+180 x 8$ & 205.4 & 0.99 \\
\hline \multirow[t]{2}{*}{9} & 265 & 344 & 229 & 263 & 141 & 344 & $775 \times 6+180 \times 8$ & 201.7 & 0.97 \\
\hline & \multicolumn{9}{|c|}{ Frame Span $24 \mathrm{~m}$} \\
\hline 6 & 324 & 321 & 178 & 317 & 169 & 324 & $750 x 6+180 \times 8$ & 198.8 & 0.96 \\
\hline 7 & 324 & 340 & 199 & 316 & 170 & 340 & $775 x 6+180 \times 8$ & 199.6 & 0.96 \\
\hline 8 & 322 & 362 & 222 & 315 & 169 & 362 & $800 x 6+180 x 8$ & 203.2 & 0.98 \\
\hline 9 & 319 & 385 & 248 & 314 & 168 & 385 & $850 \times 6+180 \times 8$ & 199.1 & 0.96 \\
\hline
\end{tabular}

Note: The yield stress $\left(\mathrm{F}_{\mathrm{y}}\right)$ is taken as $345 \mathrm{Mpa}$ with allowable stress as $0.60 \mathrm{Fy}$.

\section{3-D Analysis}

All the above frames are now analyzed as 3-D frame considering the bracings as tension only members. Major axis moment for braced and un-braced frames is compared with 2-D frame analysis showing variance upto 5\%. Minor axis moments are shown for 3-D analysis having one braced bay with as tension only members as shown in Fig 3.

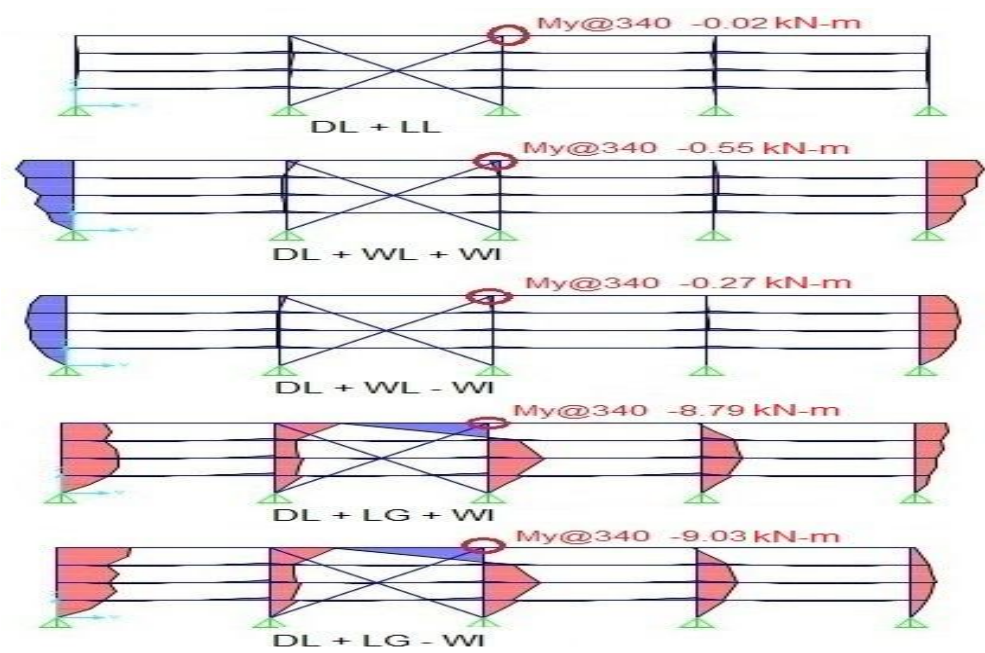

Fig.3 Minor Axis Moments For 3-D analysis with Bracing as Tension only Members 
It can be seen that for wind loads along ridge (WL-L), these are significant. From truss analogy, it can be shown that bracing force in cross bracing in wall is almost equal to that from 3-D analysis with bracing as tension only members.

Table 2 presents deflection of knee joint of braced bay for buildings with one braced bay and two braced bays for first and second order analysis. It is imperative that minor axis moment from the 3-D effects and bracing as tension only elements need to be considered in design. Deflection ratio, $\Delta_{2} / \Delta_{1}$, is 1.5 or more for both, one braced bay and two braced bays, hence second order analysis assumes significance.

For all the frames data of interaction factors are presented in Table 3. Table 3 shows that for building with one braced bay interaction factor for combined stress increases to 1.77 from maximum 0.99 and for two bays braced, it increases to 1.34. For most of the cases, governing load combination is DL+WL-L+WI i.e. (d).

From 3-D analysis, it is recommended to provide more bracing to reduce minor axis moments. Also it may be noticed that sections designed for 2-D moments are valid only for $12 \mathrm{~m}$ wide span for building braced in one bay and upto $16 \mathrm{~m}$ in case of buildings with two braced bays. For other buildings 3-D analysis is recommended.

From this data, it is observed that with increase in frame span and height, stresses due to minor axis moment become significant and should be accounted for in design especially for large spans $(>12 \mathrm{~m}$ for single bracing and $>16 \mathrm{~m}$ for other).

However practicing engineers many times resort to 2-D analysis for its simplicity. It is prudent here to evaluate minor axis moment and stresses, induced in terms of a fraction of major axis moment.

Table 2 Deflections and Deflection Ratio at Knee Joint of Braced Bay

\begin{tabular}{|c|c|c|c|c|c|c|c|}
\hline \multirow{2}{*}{ Frame Span } & \multirow[t]{2}{*}{ Height } & \multicolumn{3}{|c|}{ One Braced Bay } & \multicolumn{3}{|c|}{ Two Braced Bays } \\
\hline & & $\Delta_{1}$ & $\Delta_{2}$ & $\Delta_{2} / \Delta_{1}$ & $\Delta_{1}$ & $\Delta_{2}$ & $\Delta_{2} / \Delta_{1}$ \\
\hline $\mathrm{m}$ & $\mathrm{m}$ & $\mathrm{mm}$ & $\mathrm{mm}$ & & $\mathrm{mm}$ & $\mathrm{mm}$ & \\
\hline \multirow{4}{*}{12} & 6 & 1.53 & 2.93 & 1.92 & 0.83 & 1.58 & 1.90 \\
\hline & 7 & 2.20 & 4.19 & 1.90 & 1.16 & 2.18 & 1.88 \\
\hline & 8 & 3.12 & 5.97 & 1.91 & 1.59 & 2.99 & 1.88 \\
\hline & 9 & 4.31 & 8.26 & 1.92 & 2.17 & 4.13 & 1.90 \\
\hline \multirow{4}{*}{14} & 6 & 1.80 & 3.42 & 1.90 & 0.97 & 1.85 & 1.91 \\
\hline & 7 & 2.57 & 4.91 & 1.91 & 1.32 & 2.53 & 1.92 \\
\hline & 8 & 3.65 & 6.97 & 1.91 & 1.90 & 3.49 & 1.84 \\
\hline & 9 & 5.05 & 9.64 & 1.91 & 2.59 & 4.82 & 1.86 \\
\hline \multirow{4}{*}{16} & 6 & 2.05 & 3.78 & 1.84 & 0.99 & 1.86 & 1.88 \\
\hline & 7 & 2.96 & 5.55 & 1.88 & 1.32 & 2.83 & 2.14 \\
\hline & 8 & 4.20 & 7.83 & 1.86 & 1.86 & 3.69 & 1.98 \\
\hline & 9 & 5.78 & 10.81 & 1.87 & 2.63 & 5.15 & 1.96 \\
\hline \multirow{4}{*}{18} & 6 & 2.30 & 4.18 & 1.82 & 1.08 & 2.14 & 1.98 \\
\hline & 7 & 3.46 & 6.37 & 1.84 & 1.38 & 3.03 & 2.20 \\
\hline & 8 & 4.61 & 8.63 & 1.87 & 2.13 & 4.45 & 2.09 \\
\hline & 9 & 6.38 & 11.96 & 1.87 & 3.01 & 6.12 & 2.03 \\
\hline \multirow{4}{*}{20} & 6 & 2.65 & 4.74 & 1.79 & 1.19 & 2.36 & 1.98 \\
\hline & 7 & 3.88 & 7.06 & 1.82 & 1.50 & 3.38 & 2.25 \\
\hline & 8 & 5.13 & 9.54 & 1.86 & 2.33 & 4.94 & 2.12 \\
\hline & 9 & 7.10 & 13.23 & 1.86 & 3.31 & 6.79 & 2.05 \\
\hline \multirow{4}{*}{22} & 6 & 2.99 & 5.21 & 1.74 & 1.14 & 2.60 & 2.28 \\
\hline & 7 & 4.13 & 7.52 & 1.82 & 1.58 & 3.79 & 2.40 \\
\hline & 8 & 5.42 & 10.49 & 1.94 & 2.81 & 5.36 & 1.91 \\
\hline & 9 & 7.57 & 14.53 & 1.92 & 3.90 & 7.37 & 1.89 \\
\hline \multirow{4}{*}{24} & 6 & 3.24 & 5.58 & 1.72 & 1.28 & 2.94 & 2.30 \\
\hline & 7 & 4.26 & 8.24 & 1.93 & 1.89 & 3.89 & 2.06 \\
\hline & 8 & 5.57 & 11.27 & 2.02 & 3.41 & 5.87 & 1.72 \\
\hline & 9 & 7.88 & 15.65 & 1.99 & 4.64 & 8.07 & 1.74 \\
\hline
\end{tabular}


Table 3 Combined Unity Check For at Knee Joint - One and Two Braced Bays

\begin{tabular}{|c|c|c|c|c|c|c|c|c|c|c|c|c|c|}
\hline \multirow{3}{*}{$\begin{array}{l}\text { Hei } \\
\text { ght } \\
\text { m }\end{array}$} & \multirow{3}{*}{$\begin{array}{l}\text { Unity } \\
\text { Check } \\
\text { 2D }\end{array}$} & \multicolumn{6}{|c|}{ Unity Check - One Brace Bay } & \multicolumn{6}{|c|}{ UNITY CHECK - TWO BRACED BAYS } \\
\hline & & \multicolumn{6}{|c|}{ LOAD COMBINATIONS } & \multicolumn{6}{|c|}{ LOAD COMBINATIONS } \\
\hline & & (a) & (b) & (c) & (d) & (e) & $\max$ & (a) & (b) & (c) & (d) & (e) & $\max$ \\
\hline \multicolumn{14}{|c|}{ Frame Span $12 \mathrm{~m}$} \\
\hline 6 & 0.95 & 0.59 & 0.98 & 0.69 & 0.93 & 0.65 & 0.98 & 0.59 & 0.97 & 0.69 & 0.79 & 0.52 & 0.97 \\
\hline 7 & 0.93 & 0.49 & 0.98 & 0.73 & 0.92 & 0.68 & 0.98 & 0.51 & 0.95 & 0.72 & 0.75 & 0.52 & 0.95 \\
\hline 8 & 0.93 & 0.42 & 0.98 & 0.77 & 0.94 & 0.72 & 0.98 & 0.47 & 0.96 & 0.75 & 0.73 & 0.53 & 0.96 \\
\hline 9 & 0.94 & 0.36 & 1.00 & 0.81 & 0.99 & 0.81 & 1.00 & 0.41 & 0.98 & 0.82 & 0.74 & 0.56 & 0.98 \\
\hline \multicolumn{14}{|c|}{ Frame Span $14 \mathrm{~m}$} \\
\hline 6 & 0.96 & 0.70 & 1.00 & 0.67 & 1.08 & 0.76 & 1.08 & 0.70 & 0.98 & 0.66 & 0.92 & 0.61 & 0.98 \\
\hline 7 & 0.93 & 0.60 & 1.01 & 0.70 & 1.08 & 0.80 & 1.08 & 0.61 & 0.96 & 0.69 & 0.84 & 0.57 & 0.96 \\
\hline 8 & 0.99 & 0.52 & 0.98 & 0.73 & 1.10 & 0.86 & 1.10 & 0.58 & 0.96 & 0.72 & 0.85 & 0.62 & 0.96 \\
\hline 9 & 0.99 & 0.45 & 1.00 & 0.77 & 1.16 & 0.95 & 1.16 & 0.52 & 0.97 & 0.75 & 0.86 & 0.65 & 0.97 \\
\hline \multicolumn{14}{|c|}{ Frame Span $16 \mathrm{~m}$} \\
\hline 6 & 0.98 & 0.75 & 0.96 & 0.64 & 1.14 & 0.81 & 1.14 & 0.75 & 0.94 & 0.63 & 0.97 & 0.64 & 0.97 \\
\hline 7 & 0.95 & 0.69 & 1.01 & 0.68 & 1.17 & 0.80 & 1.17 & 0.69 & 0.98 & 0.66 & 0.98 & 0.66 & 0.98 \\
\hline 8 & 0.99 & 0.60 & 1.00 & 0.71 & 1.19 & 0.92 & 1.19 & 0.61 & 0.98 & 0.69 & 0.94 & 0.67 & 0.98 \\
\hline 9 & 0.98 & 0.53 & 1.00 & 0.74 & 1.23 & 0.99 & 1.23 & 0.53 & 0.97 & 0.72 & 0.94 & 0.70 & 0.97 \\
\hline \multicolumn{14}{|c|}{ Frame Span $18 \mathrm{~m}$} \\
\hline 6 & 0.94 & 0.84 & 1.00 & 0.61 & 1.28 & 0.90 & 1.28 & 0.84 & 0.98 & 0.60 & 1.09 & 0.72 & 1.09 \\
\hline 7 & 0.97 & 0.75 & 0.98 & 0.63 & 1.26 & 0.93 & 1.26 & 0.75 & 0.95 & 0.62 & 1.04 & 0.72 & 1.04 \\
\hline 8 & 0.95 & 0.70 & 1.03 & 0.70 & 1.34 & 1.03 & 1.34 & 0.70 & 1.00 & 0.68 & 1.07 & 0.77 & 1.07 \\
\hline 9 & 0.98 & 0.62 & 1.02 & 0.72 & 1.38 & 1.10 & 1.38 & 0.62 & 0.99 & 0.70 & 1.06 & 0.79 & 1.06 \\
\hline \multicolumn{14}{|c|}{ Frame Span $20 \mathrm{~m}$} \\
\hline 6 & 0.98 & 0.89 & 0.99 & 0.58 & 1.36 & 0.97 & 1.36 & 0.88 & 0.96 & 0.56 & 1.15 & 0.77 & 1.15 \\
\hline 7 & 0.99 & 0.85 & 1.02 & 0.63 & 1.40 & 1.04 & 1.40 & 0.83 & 0.99 & 0.62 & 1.16 & 0.80 & 1.16 \\
\hline 8 & 0.97 & 0.75 & 1.00 & 0.65 & 1.45 & 1.13 & 1.45 & 0.75 & 0.98 & 0.63 & 1.15 & 0.83 & 1.15 \\
\hline 9 & 0.95 & 0.71 & 1.04 & 0.71 & 1.54 & 1.23 & 1.54 & 0.71 & 1.01 & 0.69 & 1.18 & 0.88 & 1.18 \\
\hline \multicolumn{14}{|c|}{ Frame Span $22 \mathrm{~m}$} \\
\hline 6 & 0.96 & 0.93 & 0.99 & 0.56 & 1.43 & 1.04 & 1.43 & 0.93 & 0.97 & 0.55 & 1.22 & 0.82 & 1.22 \\
\hline 7 & 0.97 & 0.90 & 1.01 & 0.60 & 1.53 & 1.14 & 1.53 & 0.88 & 0.98 & 0.59 & 1.24 & 0.87 & 1.24 \\
\hline 8 & 0.99 & 0.85 & 1.03 & 0.65 & 1.60 & 1.25 & 1.60 & 0.88 & 1.00 & 0.63 & 1.26 & 0.91 & 1.26 \\
\hline 9 & 0.97 & 0.78 & 1.01 & 0.67 & 1.67 & 1.36 & 1.67 & 0.80 & 0.98 & 0.65 & 1.27 & 0.95 & 1.27 \\
\hline \multicolumn{14}{|c|}{ Frame Span $24 \mathrm{~m}$} \\
\hline 6 & 0.96 & 0.97 & 0.99 & 0.55 & 1.50 & 1.10 & 1.50 & 0.98 & 0.97 & 0.53 & 1.28 & 0.87 & 1.28 \\
\hline 7 & 0.96 & 0.95 & 1.00 & 0.58 & 1.61 & 1.21 & 1.61 & 0.93 & 0.96 & 0.57 & 1.28 & 0.90 & 1.28 \\
\hline 8 & 0.97 & 0.92 & 1.01 & 0.62 & 1.69 & 1.33 & 1.69 & 0.95 & 1.00 & 0.60 & 1.33 & 0.96 & 1.33 \\
\hline 9 & 0.99 & 0.85 & 0.99 & 0.64 & 1.77 & 1.44 & 1.77 & 0.88 & 0.98 & 0.62 & 1.34 & 1.01 & 1.34 \\
\hline
\end{tabular}

\section{Approximate Evaluation of Minor Axis Moment}

In absence of 3-D analysis, minor axis moment at knee may be estimated as explained here. Let us consider ratio of minor axis moment to major axis moment at knee joint as $\Psi$. Term $\Psi_{\text {one }}$ refers to building with one braced bay and $\Psi_{\text {two }}$ refer to building with two braced bays. Fig. 4 presents plot showing variation of $\Psi_{\text {one }}$ and $\Psi_{\text {two }}$ with increasing value of ratio $\mathrm{h} / \mathrm{w}$.

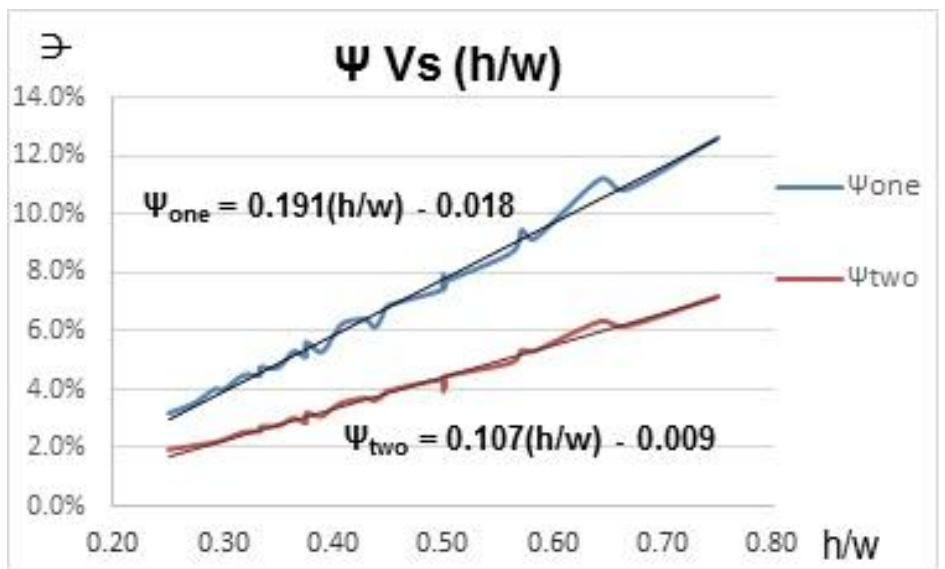

Fig. 4 Ratio of Minor Axis to Major Axis Moment, $\Psi$ Versus h/w Ratio

It can be used to evaluate minor axis moment for may be expressed as $\mathrm{M}_{\mathrm{y}}=\mathrm{M}_{\mathrm{z}} . \Psi$

For building with one braced bay,

$\Psi=\Psi_{\text {one }}=0.191(\mathrm{~h} / \mathrm{w})-0.018$ 
For building with two braced bays, $\Psi=\Psi_{\mathrm{two}}=0.107(\mathrm{~h} / \mathrm{w})-0.009$

It can be seen that this approximate method allows designer to adopt 2-D mathematical model for analysis and consider approximately the minor axis moment using Fig. 4.

\section{Conclusions}

From the above study, following observations are summarized.

1. 3-D analysis of frames indicates that major axis moments for braced frames and unbraced frames are within $5 \%$ of 2-D analysis results. For all practical purposes, major axis moment can be considered as design moment as obtained by 2-D analysis. Second order analysis shows insignificant variation in major axis moment.

2. Axial forces in wall bracing in second order analysis are comparable to bracing forces as calculated by truss action.

3. Minor Axis moments are induced in braced frames due to bracing forces (especially in cross bracing designed as tension only member), which significantly affects the design.

4. In most of the PEB structures, the ratio of deflections at knee joint in direction of ridge from second order analysis versus first order, $\Delta_{2} / \Delta_{1}$, is 1.5 or more, thus qualifies the frame for second order analysis.

5. Increasing number of braced frames reduces minor axis moments in the frames indicating distribution of longitudinal forces in braced frames. Hence more braced frames should be provided in each building as a norm.

6. For braced frames, optimized design of frame member on 2-D analysis basis may not be safe considering the effect of stresses due to minor axis moments.

7. Ratio of building height to building width is significant in determining ratio of minor axis moment to major axis moment.

8. Attempt has been made to evaluate Minor axis moment from major axis moment which will be helpful in case of design by 2-D analysis where minor axis moment can be accounted for in design by the approximate method.

9. Ratio of minor axis moment to major axis moment, $\Psi$ and corresponding equations with respect to $\mathrm{h} / \mathrm{w}$, may vary with change in wind speed zone.

10. In case designed only for 2-D analysis and minor axis moment are not accounted for, bracing should be designed for tension as well as compression forces also.

\section{Notations}

Following symbols are used in this paper.

$\mathrm{F}_{\text {actual }}=$ Actual Bending Stress, Mpa.

$\mathrm{F}_{\text {allow }}=$ Allowable Bending Stress, Mpa.

$\mathrm{F}_{\mathrm{y}}=$ Yield Stress, Mpa.

$\mathrm{I}_{\mathrm{Z}}=$ Moment $\mathrm{Of}$ Inertia about $\mathrm{Z}$ axis

$\mathrm{I}_{\mathrm{y}}=$ Moment Of Inertia about $\mathrm{Y}$ axis

$\mathrm{M}_{\mathrm{z}}=$ Major Axis Moment, $\mathrm{kN}-\mathrm{m}$.

$\mathrm{M}_{\mathrm{zd}}=$ Design Major Axis Moment, $\mathrm{kN}-\mathrm{m}$.

$\mathrm{M}_{\mathrm{y}}=$ Minor Axis Moment, $\mathrm{kN}-\mathrm{m}$.

$\mathrm{S}_{\mathrm{z}}=$ Section Modulus about $\mathrm{Z}$ axis

$\mathrm{S}_{\mathrm{y}}=$ Section Modulus about $\mathrm{Y}$ axis

$\Delta_{1}=$ Deflections at knee along ridge from first order analysis, $\mathrm{mm}$.

$\Delta_{2}=$ Deflections at knee along ridge from second order analysis, $\mathrm{mm}$.

$\Psi=$ Ratio of Minor Axis Moment to Major Axis Moment at Knee.

$\Psi_{\text {one }}=\Psi$ for building with one braced bay.

$\Psi_{\text {two }}=\Psi$ for building with two braced bays.

\section{References}

[1]. AISC, Steel Construction Manual, $14^{\text {th }}$ edition(2011), $13^{\text {th }}$ edition(2005), ASD manual (1989 edition).

[2]. AISC Steel Design Guide Series 25 (2009), Frame Design Using Web-Tapered Members, MBMA/AISC. Compiled by Richard C. Kaehler, Donald W. White, Yoon Duk Kim.

[3]. Newman A., Metal Building Systems, Design and Specifications $2^{\text {nd }}$ edition (McGraw-Hill Publications 2005)

[4]. IS 800:1984. Indian Standard Code of Practice for General Construction In Steel.

[5]. IS 800:2007. Indian Standard. General Construction in Steel-Code of Practice.

[6]. IS 875:1987. Indian Standard Code of Practice for Design Loads (Other than Earthquake) for Buildings and Structures.

[7]. Subramanian, N., Design Of Steel Structures (Oxford Press 2008)

[8]. Galambos T.V. and Surovek A,.E, Structural Stability of Steel: Concepts and Applications for Structural Engineers (John Wiley \& Sons, Inc. 2008) 